\title{
A PROPOSED MODEL FOR MEASURING ECONOMIC AND ENVIRONMENTAL EFFECTS OF INVESTMENT IN CHEMICAL INDUSTRIES - APPLIED STUDY
}

\author{
El- Adel, M. R. A. ${ }^{(1)}$; Rabie, A. M. ${ }^{(2)}$ and Nasr Eldien, Mervat ${ }^{(3)}$ \\ 1) Dept. of Economy, Faculty of Commerce, Ain Shams University 2) Dept. \\ of Chemistry, Faculty of Science, Ain Shams University 3) R\&D Sector, \\ Holding Company for chemical industries.
}

\begin{abstract}
According to the sustainable development concept there is a very important relationship between the economic development and environment protection against various types of contaminations and pollutions,especially; those caused by chemical industrial firms. Unfortunately, many firms suffer from equipment aging, old, and small production-units employ obsolete technologies. The factories rehabilitation or replacement of the worn-out equipment with the new, modern, and environmentally friend technologies require investments. This paper addresses the problem of industrial pollution and measuring the economic and environmental effects of investment in the chemical industries.The research sample includes El Nasr Company for Fertilizers and Chemical Industries "SEMADCO" and The Egyptian Chemical Industries Company "KIMA". "SEMADCO" and "KIMA" firms are Egyptian contributing companies belonging to the Chemical Industries Holding Company (CIHC) and the Ministry of Public Business Sector (MPBS) in A. R. E.It is concluded that the more efficient investments in chemical industries the less the harmful environmental effects of chemical industries. The less the harmful environmental effects of chemical industries the more investments economic benefits in chemical industries. The more the costs of pollution prevention the less the harmful environmental effects of the chemical industries.It is recommended that the firm's management give more attention for the efficient investments with great feasibility studies. Such investment has economic; "more financial benefits" and environmental benefits; "less harmful environmental effects". Also, It is recommended that the firm's management taking in consideration the proposed model for the
\end{abstract}


accounting disclosure of environmental information. As that disclosure has great importance in the field of planning and controlling to protect the environment from pollution risks caused by the chemical firms.

\section{INTRODUCTION}

The chemical industry comprises the companies that produce industrial chemicals. It converts raw materials (oil, natural gas, air, water, metals, and minerals) into more than 70,000 different products.

This paper will be confined to Chemical Industries Holding Company (CIHC) and, two firms of its affiliated Companies. In Egypt, Chemical Industries Holding Company (CIHC) is one of the biggest organizations in the field of chemicals production. It is the major shareholder of 18 large and medium chemical Industries Companies. These companies are located at different Governorates in Egypt, so the products are easily accessed. The paid-up capital of the affiliated companies is about 2.5 billion Egyptian pounds (L.E.), the annual revenues in 30/6/2015 amounted to about 10 billion L.E.

The production of the affiliated companies covers a wide spectrum. It includes:nitrogenous fertilizers sector, essential \& miscellaneous chemicals sector, tires, rubber \& leather products sector, industrial \& edible salt sector, electric lambs' factory sector, paper sector, cement, mining \& cement products sector, cigarettes and related sector, transportation requirements sector, and trading sector (CIHC General Assembly Reports, ((2011/2012) (2014/2015)). 
Since the 1991, the Egyptian government has adopted and implemented a comprehensive economic program. The Chemical Industries Holding Company (CIHC) works in accordance with spirit of this program and in conformity with the Law No. 203 for 1991 and its by-law.

The chemical industries play a critical role in the environmental pollution. The pollution may be air pollution due to gas emissions of $\mathrm{COx}$, SOx, and NOx, or may be pollution due to liquid and solid wastes. On the other hand; the industrial firms have to disclose and show clearly the expenditure incurred by them in their activities separated from environmental expenditure such as the preventive or therapeutic expenditure or any expenditure used for the protection of the various elements of the environment (S\&WMCI STONE, (1998)).

The evolution concept of development has led to increased attention to environmental issues. It can't be ignored; either in the application of development policies or when studying the economic feasibility of the projects and seeking to achieve sustainable development.

The manifestation of this interest is shown clearly, in consciousness of the need to assess the environmental impacts of contaminated industrial chemicals.

\section{RESEARCH PROBLEM}

The research addresses the problem of industrial pollution and measuring the economic and environmental effects of investment in the chemical industries. 
According to the Law 4/1994 for the Protection of the Environment and its amendment by law 9/2009, the national monitoring network of industrial emissions of the Egyptian Environmental Affairs Agency (EEAA) is one of the basic tools to follow-up the implementation of protection and promotion of the environment plans with competent administrative authorities. Also, collect data and information on emissions quality and its quantity and the analysis of these data contributes effectively to the control process in industrial pollution, and also contribute in giving a clear picture of air quality in places located nearby those companies through analysis of pollution loads, where they can use the data collected in reports including the following: Estimating the size of the emission and its timely development of its rates. Follow-up of compatibility of emissions with limits prescribed by law No. 4 of 1994 on the protection of the environment. The possibility of making a comparison of the rates of pollution in different places. The possibility of assessing the health and economic impacts resulting from emissions released in case of the availability of tools for that assessment. Effective contribution in the evaluation of the maximum limits set forth in the Regulations to Law No. 4 of 1994.Environmental assessment of the surrounding areas, as well as its evaluation on the strategic level. Monitoring of the compatibility of emissions from these stacks more accurately without interference by the companies in determining the quality, the form and timing of available data. Accounting of environmental loads of emissions 


\section{RESEARCH AIMS}

The aim of this work is to propose a model for measuring the economic and environmental effects of investment in chemical industries.

\section{RESEARCH HYPOTHESIS}

The research hypothesis in concern involves the following three significant relationships: a) between decreasing the harmful environmental effects of chemical industries and increasing investments. b) between increasing the investment economic benefits in chemical industries and decreasing the negative environmental effects of these chemical industries. c) between increasing the costs of pollution prevention and decreasing the harmful environmental effects of the chemical industries

\section{RESEARCH IMPORTANCE}

Importance of such research is due to the development and economic growth in the recent years. As economic growth increases, the chemical products output increases rapidly. However, this growth should consider the cost of environmental pollution.Industrial development and technological progress may be regarded as the main factors of the pollution. There is a need for more regulations and procedures to mitigate environmental pollution and negative environmental effects of economic establishments and chemical industrial development. There is a need for more investment in pollution control.These exist an international concern and possible assistance which might decrease the local cost of removal pollution (UNCTAD Secretariat,(1998); S\&WMCI, (1998); UNDSD, (2001)). 
J. Environ. Sci.

Institute of Environmental Studies and Research - Ain Shams University

\section{REVIEW OF LITERATURE}

In the literature Brath M. and M. MeNichols, (1994)) study was conducted in the United States. It is looking to predict the environmental obligations concerning the protection of the environment from pollution. It shows the need to measure the financial burdens resulting from the acquisition of the economic firm for the assets with advanced technology to remove or prevent the causes of pollution. Also, it shows importance of the firm responsibility for removal of the pollution reasons resulting from its operations pollution.The study concluded that the need to measure the environmental performance and disclosure about the future for social performance, both in the traditional menus or in separate lists.

(Al-Rifai, Baseel, and Elham, (2008)) study shows the economic impacts for the pollution that resulted from industrial firms, and the effects of the consequences costs for these impacts on the environment. It is concluded that accounting plays a role in protecting the environment and reduces pollution through standards and especial disclosures. It embodies environmental accounting concept which is relatively new applied in Syria. The possibility of measuring the environmental accounting of the expenditure is available; and it is needed to modify the accounting system to be agreed with international standards and principles of environmental accounting. Thedisclosure ofthe terms ofthe environmental costsin the companyisnotdifficult;most ofthese costs areeasy tomeasure andestimateits values. It needs toorganize in the accounting itemsin the industrial costs statementand with according tostandards. Those standards must be 
established bythe used accounting system. The role played by accounting in the reduction of environmental pollution is to show the size of the expenditure incurred by the company in its activities and the preventive or therapeutic expenditure for the protection of the various elements of the environment.

\section{CONCEPTS}

Sustainable Development Definition: Sustainable Development defined as "development that meets the needs of the present without compromising the ability of future generations to meet their own needs"(UNDSD, (2001)).

Environmental Disclosure: Disclosure of information relating to environmental costs and liabilities is important for the purpose of clarifying or providing further explanation of the items included in the balance sheet or the income statement. Such disclosures can either be included in those financial statements, in the notes to the financial statements or, in certain cases, in a section of the report outside the financial statements themselves. In deciding on whether an item of information, or an aggregate of such items, should be disclosed, consideration should be given as to whether the item is material. In determining materiality, consideration would be given not only to the significance of the amount, but also to the significance of the nature of the item. The costs of providing the information should bear a reasonable relationship to the benefits derived therefrom. It is also necessary to take into account the need of the enterprise to maintain business confidentiality in sensitive areas, so as not to jeopardize its competitive position or its ability to continue its operations(UNCTAD Secretariat,(1998);UNDSD, (2001)). 
J. Environ. Sci.

Institute of Environmental Studies and Research - Ain Shams University

\section{PROCEDURES}

Methodology: using inductive inference method. Also, usingdescriptive analytical method for addressing the research hypothesis.

Data: given from the firms documents and records

Sample: "SEMADCO"firm and "KIMA" firm

Period: from July 2011 to September 2012 at SEMADCO plant, Suez governorate. Between 2011/2012 - 2014/2015 at KIMA plant, Aswan governorate.

\section{RESULTSAND DISCUSSION}

The proposed model consists of two parts. The first part is two cases study for two affiliated companies of the research sample company (The Chemical Industries Holding Company (CIHC)) to verify the abovementioned hypothesis. The second part is concerned with the disclosure. It is both of an amended (adjusted) balance sheet and adjusted income statement. It integrates the economic and environmental dimensions to set a comprehensive framework for disclosure about financial and environmental activities. The Traditional balance sheet or income statement produced according to the Uniform Accounting System shows only the economical dimensions. It concentrates on the financial activities without any considerations regarding the environmental dimensions.

The first case study is "SEMADCO" rehabilitation. "SEMADCO" is El Nasr Company for Fertilizers and Chemical Industries. "SEMADCO" is Egyptian contributing company belonging to the Chemical Industries Holding Company (CIHC) and the Ministry of Public Business Sector (MPBS) 
locating in Suez Arab Republic of Egypt. The company works in the field of production and marketing of nitrogenous fertilizers, liquid and solid chemicals.The authorized capital of 500 million and paid 221 millionE.P.The plan of the rehabilitation is started at January 2009 in three stages to enhance environmental and economic performance of the company in the coordination with the Holding Company for Chemical Industries, investment cost about 180 million pounds. At January 2012 the plan of the factories development with financial cost 200 million has been completed which was reflected positively on the financial position of the "SEMADCO" company and turned from the ranks of losers companies to the ranks of winner companies, the net profit about 20 million since loading factories in January 2012 to June 2012 and during the months of July, August and September 2012, about 29 millionE, $\mathrm{P}$.

The work performed in the ammonia unit included main revamping works of primary reformer, low shift converter, as well as installation of a new air compressor and inspection / repairs of all synthesis and natural gas compressors, inaddition of the installation of the CASALE converter's cartridge and the burner of the secondary reformer, after almost 19 years of operation, also lot of works in the utilities sections. This is a really enlarged overall revamping of the ammonia unit, which constitutes a real professional remarkable long-term performance. Ammonia Casale Department Head Research \& Technology Development highlight that with such improvements, the ammonia unit should be ready to produce more than its original 400 TPD (tons/day) nominal capacity and that this is an excellent start for a planning to increase the capacity of the unit, by relatively few additions of equipment, 
which should lead to an ammonia production increase (SEMADCO Board Reports, (2011/2012 - 2014/2015)).

The revamping process shows that the company was suffering from many problems. One of most important is equipmentcorrosion. It leads to leaking of chemical substances, water, and consequently overused resources (electricity and natural gas), and extra production costs. On other side; it leads to more harmful environmental effects (emissions and wastes) and of course to a financial loss.

The performance rates of ammonia department (400 tons/day) before and after maintenance are shown in table (1).

Table (1): Natural Gas Consumption and The performance Rates of Ammonia Department

\begin{tabular}{|c|c|c|c|c|}
\hline Capacity & $\begin{array}{c}\text { After } \\
\text { maintenance } \\
\text { at capacity } \\
\mathbf{6 0 \%}\end{array}$ & $\begin{array}{c}\text { Before } \\
\text { maintenance } \\
\text { at capacity } \\
\mathbf{6 0 \%}\end{array}$ & $\begin{array}{c}\text { Before } \\
\text { maintenance } \\
\text { at capacity } \\
\mathbf{7 5 \%}\end{array}$ & $\begin{array}{c}\text { Designed } \\
\text { Capacity at } \\
\text { capacity } \\
\mathbf{1 0 0 \%}\end{array}$ \\
\hline $\begin{array}{c}\text { Gas/Ton } \\
\text { Ammonia }\end{array}$ & $872 \mathrm{~m} 3$ & $1161 \mathrm{~m} 3$ & $1424 \mathrm{~m} 3$ & $853 \mathrm{~m} 3$ \\
\hline
\end{tabular}

Firstly, it is known that the natural gas is the main element in the fertilizer industry whereammonia (NH3)can be synthesized by obtaining nitrogen (N2) from air (air is approximately $78 \%$ nitrogen, $21 \%$ oxygen and $1 \%$ argon with traces of other gases), and hydrogen (H2) from natural gas (CH4).Secondly, from table (1), and by the comparison between the consumed amount of gas per each produced ton of ammonia before and after maintenance at capacity $60 \%$; it is seen that the gas amount reduced from $1161 \mathrm{~m} 3$ to $872 \mathrm{~m} 3$. This means that the maintenance led to saving about 289 
m3 of the natural gas per each produced ton of ammonia. In addition, the revamped ammonia unit, once reaching the $100 \%$ production capacity, will surely demonstrate important energy savings (electricity and gas amounts). Consequently, energy savings will lead to reducing costs and increasing benefits (revenue). The above-mentioned facts and conclusion can be shown more clearly through exploring the real data about ammonia production, consumed natural gas, and consumed electricity.

Table (2): Ammonia Production, Consumed Natural Gas, Consumed Electricity, and Gas Costs from July 2011 to March 2012

\begin{tabular}{|c|c|c|c|c|c|c|c|}
\hline Item & $\begin{array}{c}\text { July } \\
\mathbf{2 0 1 1}\end{array}$ & $\begin{array}{c}\text { August } \\
\mathbf{2 0 1 1}\end{array}$ & $\begin{array}{c}\text { September } \\
\mathbf{2 0 1 1}\end{array}$ & $\begin{array}{c}\text { October } \\
\mathbf{2 0 1 1}\end{array}$ & $\begin{array}{c}\text { January } \\
\mathbf{2 0 1 2}\end{array}$ & $\begin{array}{c}\text { February } \\
\mathbf{2 0 1 2}\end{array}$ & $\begin{array}{c}\text { March } \\
\mathbf{2 0 1 2}\end{array}$ \\
\hline \hline $\begin{array}{c}\text { Produced } \\
\text { Ammonia / } \\
\text { Ton }\end{array}$ & 5871 & 6360 & 5222 & 5847 & 6780 & 7410 & 7940 \\
\hline $\begin{array}{c}\text { Natural } \\
\text { Gas } \\
\text { Quantity / } \\
\text { 1000 m3 }\end{array}$ & 12388 & 14240 & 13441 & 13434 & 12991 & 12868 & 13671 \\
\hline $\begin{array}{c}\text { Electricity / } \\
\text { mega watt }\end{array}$ & 2183 & 2662 & 1501 & 1781 & 1145 & 1259 & 1264 \\
\hline \hline
\end{tabular}

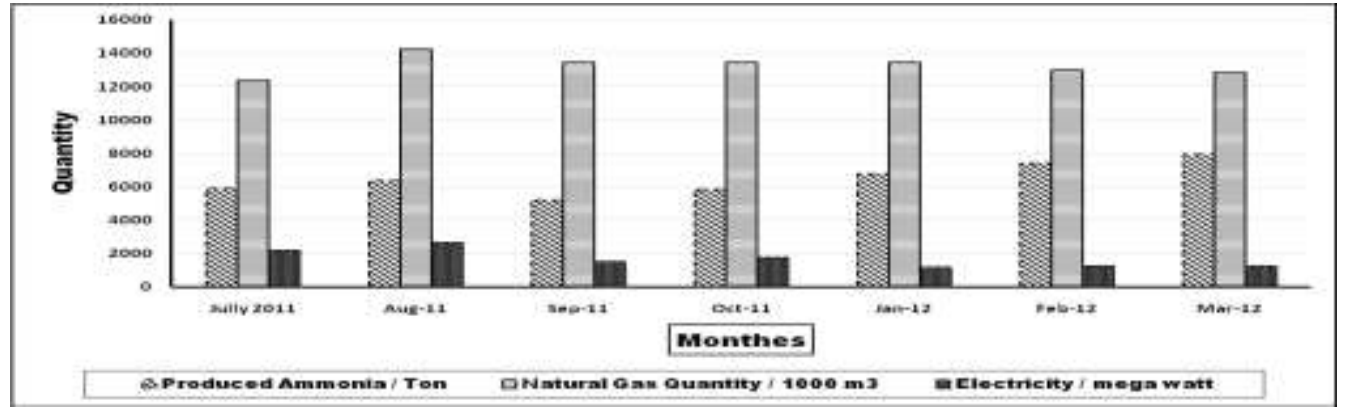

Figure (1): Ammonia Production, Consumed Natural Gas, and Consumed Electricity from July 2011 to March 2012 
From table (2) and figure (1); it is shown that there is a relationship between ammonia productions, consumed natural gas, and consumed electricity, through a period from July 2011 to March 2012. It indicates that there is increasing in Ammonia Production while there is decreasing in consumed natural gas, and consumed electricity.

Mapping for above mentioned relationships with the research hypothesis which mentioned previously. In "SEMADCO" firm case the harmful environmental effects are clearly shown as in above mentioned ammonia production example andcan be summarized in certain aspects such as overused resources (electricity and natural gas), extra harmful emissions than the permitted levels, leaking of chemical substances. All these aspects changed to positive direction through investments in the rehabilitation (revamping) process.It means thatthe more efficient investments in chemical industries the less the harmful environmental effects of chemical industries. Regarding to the significant relation between increasing the investment economic benefits and decreasing the negative environmental effects of this chemical industries.Energy savings and leaking prevention lead to reducing costs and increasing benefits (revenue). It is reflected positively on the financial position of the "SEMADCO" company and turned from the ranks of loser companies to the ranks of Winner companies.It means thatthe less the harmful environmental effects of chemical industries the more investments economic benefits in chemical industries.Regarding to the significantrelation between increasing the costs of pollution prevention and decreasing the harmful environmental effects of the chemical industries. In "SEMADCO" 
case; investments in the Rehabilitation (Revamping)process includes the costs of many items that prevent or minimize pollution such as costs of corrosion repairing, costs of filters, and costs of replacing damaged parts.It means that the more the costs of pollution prevention the less the harmful environmental effects of the chemical industries.

Generally, it is concluded from the previous relations that investments may have two positive wings, especially when investments are well studied and applied via great feasibility studies. One is economic; "more financial benefits" and the other is environmental; "less harmful environmental effects". Then it called efficient investments. Such positive roles (investments wings) can be reflected financially (economic) in the balance sheet but unfortunately; environmentally cannot be reflected via these sheets. On other word there is inefficiency of traditional (classical or current) balance sheets in disclosure of accounting information concerned with environmental activities. Economic-Environmental Income Statement (EEIS) model: Such a statement represents (expresses) a final major account under the unified accounting system, and therefore the final result detects profit or "loss" (excess (surplus) or "deficit") of the company activities. The incorporation of the environmental dimension within the meaning revealed income statement means that it contains running costs borne by the company as a result of its economic activity, in addition to the ongoing (running) environmental costs carried by the company for the preservation of the environment from pollution caused as a result of its operations productivity. The environmental costs include salaries and wages paid to workers in the field of protection of 
J. Environ. Sci.

Institute of Environmental Studies and Research - Ain Shams University

the environment and cost of goods and services needs. Economic Environmental Income Statement is shown in figure (2).

Figure (2): Economic-Environmental Income Statement Model for "SEMADCO".

\begin{tabular}{|c|c|c|c|c|}
\hline Total & Part & Description & $\begin{array}{c}\text { Accounting } \\
\text { Guide }\end{array}$ & $\begin{array}{c}\text { Comparison } \\
\text { Year }\end{array}$ \\
\hline & & Revenue Activity & 41 & \\
\hline & & Net sales of end products & 411 & \\
\hline & & Services sold & 414 & \\
\hline & & Processing income for others & 415 & \\
\hline & & Other income activity & 417 & \\
\hline & & & & \\
\hline & & Subtraction of & & \\
\hline & & $\begin{array}{l}\text { The cost of production or purchase } \\
\text { of units sold }\end{array}$ & 36 & \\
\hline & & $\begin{array}{c}\text { Marketing Costs (selling and } \\
\text { distribution) }\end{array}$ & 37 & \\
\hline & & The Cost of Activity Revenues & & \\
\hline & & Subtraction of concern environment & & \\
\hline & & $\begin{array}{l}\text { The cost of production or purchase } \\
\text { of units sold }\end{array}$ & & \\
\hline & & $\begin{array}{c}\text { Marketing Costs (selling and } \\
\text { distribution) }\end{array}$ & & \\
\hline & & The Cost of Activity Revenues & & \\
\hline & & Gross profit (loss) & & \\
\hline & & In Addition to & & \\
\hline & & Investment income & 43 & \\
\hline & & $\begin{array}{l}\text { Investment income and other } \\
\text { financial }\end{array}$ & 433 & \\
\hline & & Other income and profits & 44 & \\
\hline & & $\begin{array}{c}\text { Negated the purpose of the } \\
\text { provisions (other than AD. Falling } \\
\text { prices) }\end{array}$ & 441 & \\
\hline & & A variety of revenue and profit & 444 & \\
\hline & & Less than & & \\
\hline & & Administrative Expenses & & \\
\hline
\end{tabular}


Cont. Figure (2):

\begin{tabular}{|c|c|c|c|c|}
\hline Total & Part & Description & $\begin{array}{c}\text { Accounting } \\
\text { Guide }\end{array}$ & $\begin{array}{c}\text { Comparison } \\
\text { Year }\end{array}$ \\
\hline & & $\begin{array}{c}\text { Salaries and allowances of the presence } \\
\text { and movement of Board members }\end{array}$ & 31 & \\
\hline & & Other administrative expenses & & \\
\hline & & Less than concern environment & & \\
\hline & & Administrative Expenses & & \\
\hline & & $\begin{array}{l}\text { Salaries and allowances of the presence } \\
\text { and movement of Board members }\end{array}$ & & \\
\hline & & Other administrative expenses & & \\
\hline & & Burdens and Losses & 35 & \\
\hline & & $\begin{array}{c}\text { Benefits (other depreciation and falling } \\
\text { prices of their stock allocations) }\end{array}$ & 351 & \\
\hline & & Burdens and a variety of Losses & 354 & \\
\hline & & $\begin{array}{l}\text { Net Earnings (Loss) of the activity } \\
\text { before financing expenses and } \\
\text { benefits payable }\end{array}$ & & \\
\hline & & Financing Expenses & 333 & \\
\hline & & $\begin{array}{c}\text { Financing Expenses concern } \\
\text { environment }\end{array}$ & & \\
\hline & & Interest Income & 435 & \\
\hline & & Net Earnings (Loss) of the activity & & \\
\hline & & & & \\
\hline & & Add to (deduct from) & & \\
\hline & & $\begin{array}{l}\text { Profit (Loss) on exchange } \\
\text { differences }\end{array}$ & $445(335)$ & \\
\hline & & Income (expense) prior years & $446(356)$ & \\
\hline & & Profit (Loss) on capital & $447(357)$ & \\
\hline & & $\begin{array}{l}\text { Revenue and earnings (Loss) on } \\
\text { ordinary }\end{array}$ & $448(358)$ & \\
\hline & & Net Profit (Loss) before Income Taxes & & \\
\hline & & Income Taxes & 359 & \\
\hline & & & & \\
\hline & & Net Profit (Loss) & & \\
\hline
\end{tabular}


J. Environ. Sci.

Institute of Environmental Studies and Research - Ain Shams University

Economic - Environmental Balance Sheet (EEBS) model: economic environmental Balance sheet; the preparation of this disclosure sheet based on the separation of fixed and current assets used by the company in its production operations far from those used to protect the environment from pollution. Also, taking costs into consideration, especially those concerned with purchase of the necessary fixed assets and capital additions (that the company intends to develop it for the expansion and environmental purposes) to protect against contamination, as well as deferred (postponed) environmental expenses, which include research expenses, exploration expenses, and experiments expenses carried out by the company in order to develop its operations in line with the environmental protection requirements. It should be noted that there is no a total separation of the final accounts in line with the numbers of the proposed model for the disclosure requirements, due to the company failureto separate of the economic activities costs from those costs incurred for environmental purposes.Economic - Environmental Income Statement is shown in figure (3).

Figure (3): Economic - Environmental Balance Sheet Model for "SEMADCO".

\begin{tabular}{|c|c|c|c|c||}
\hline Total & Part & Description & $\begin{array}{c}\text { Accounting } \\
\text { Guide }\end{array}$ & $\begin{array}{c}\text { Comparison } \\
\text { Year }\end{array}$ \\
\hline \hline & & Economic Long-Term Assets & & \\
\hline & & Economic Fixed Assets & 11 & \\
\hline & & Projects under Implementation & 12 & \\
\hline & & Long-term Investments & 13 & \\
\hline & & Investments in Bonds & 135 & \\
\hline & & Economic deferred revenues expenses & 15 & \\
\hline & & Total Economic Long-Term Assets (1) & & \\
\hline
\end{tabular}




\section{Cont.Figure (3):}

\begin{tabular}{|c|c|c|c|c|}
\hline Total & Part & Description & $\begin{array}{l}\text { Accounting } \\
\text { Guide }\end{array}$ & $\begin{array}{c}\text { Comparison } \\
\text { Year }\end{array}$ \\
\hline & & Stock & 16 & \\
\hline & & $\begin{array}{c}\text { Letters of Credit for Purchase of Goods } \\
\text { and Services }\end{array}$ & 166 & \\
\hline & & $\begin{array}{l}\text { Customers and Cashing Paper and Debit } \\
\text { Accounts } \\
\end{array}$ & 17 & \\
\hline & & Cash in banks and The Fund & 19 & \\
\hline & & Total Economic Current Assets & & \\
\hline & & Total Economic Assets & & \\
\hline & & Environmental Assets & & \\
\hline & & Environmental Fixed Assets & 11 & \\
\hline & & $\begin{array}{l}\text { Environmental Projects under } \\
\text { Implementation }\end{array}$ & 12 & \\
\hline & & $\begin{array}{c}\text { Environmental deferred revenues } \\
\text { expenses }\end{array}$ & 15 & \\
\hline & & Total Environmental Fixed Assets & & \\
\hline & & Environmental current Assets & & \\
\hline & & Stock of Environmental matters & 16 & \\
\hline & & $\begin{array}{l}\text { Letters of Credit for Purchase of } \\
\text { Environmental Goods and Services }\end{array}$ & 166 & \\
\hline & & Total Environmental Current Assets & & \\
\hline & & Total Environmental Assets & & \\
\hline & & Total Economic- Environmental Assets & & \\
\hline & & Current Liabilities & & \\
\hline & & Provisions & 26 & \\
\hline & & Suppliers & 28 & \\
\hline & & Total Current Liabilities & & \\
\hline & & Working Capital (2) & & \\
\hline & & $\begin{array}{l}\text { Total Investment }(1+2) \\
\text { And is financed as follow: }\end{array}$ & & \\
\hline & & Property Rights & 2 & \\
\hline & & Capital Source & 21 & \\
\hline & & Paid-in Capital & & \\
\hline & & Reserves & 22 & \\
\hline & & Total Equity (3) & & \\
\hline & & Long-term Liabilities & 25 & \\
\hline & & Loans & & \\
\hline & & Total Long-term Liabilities (4) & & \\
\hline & & Total Investment Financing $(3+4)$ & & \\
\hline
\end{tabular}

Vol.42, No.1, Jun. 2018 
Case Study 2 is "KIMA" Modernization and Expansion. "KIMA" is The Egyptian Chemical Industries Company. It is a joint stock Egyptian public company. " KIMA " is works in the field of production and marketing of nitrogenous fertilizers and is belonging to the Holding Company for Chemical Industries and the Ministry of Public Business Sector. The Company founded on 1956. "KIMA" factories and its residential city had established on a 1107 Acre in the south east of Aswan city with approximately four kilometers on the Aswan - El Sad El Ally Road. The idea of establishing "KIMA" in Aswan city came to exploit the electric power that came from the electric station of Aswan Dam year of 1956 for the possibility of exploiting the surplus part from the station power which produce $280 \mathrm{MW}$. "KIMA" consume approximately 200 to $220 \mathrm{MW}$ and consume the bigger part of that in the electrolysis operations for the water where the raw materials are (electricity - water - air).The permitted capital is 2 billion Egyptian pounds.

Technical Constrains of the Current "KIMA" Plant: The currently existing "KIMA" plant had established since 1956 and had more than 60 years ago. The plant is old, with small-scales multiple units. Most of those units are worn out and employ obsolete technologies. As a result, energy consumption for ammonia (main element for fertilizers industry) production is about 32 giga calories (Gcal) / ton compared to $7 \mathrm{Gcal} /$ ton in modern ammonia plants employing the latest low-energy designs. On the other hand; the nitric oxide (NOx) and ammonia emission levels are high, causing serious pollution problems. "KIMA" suffer from equipment aging and consequently; 
the production depends on old technology. "KIMA" consume approximately 200 to $220 \mathrm{MW}$ and consume the bigger part of that in the electrolysis operations for the water where the raw materials are (electricity - water air).The huge problem is electrical current cut or decreasing. It occurs for about 129 times / year. Sometimes the electrical current cut or decreasing occurs day after day. Such a problem is a crisis for the heavy industries like fertilizers industry. It leads to plant stops completely or decreasing operation load percentage and many difficulties for achieving the production plan,in addition to losing billions of Pounds, and more environmental pollution problems.

Natural Gas-Based "KIMA" New Project: An objective of the preinvestment study is to provide a techno-economic analysis of the optimum way of modernization, restructuring, and expansion of the production facilities in and around the "KIMA" fertilizer complex at Aswan. Based on the assumption that natural gas can be made available to the complex, nitrogen/hydrogen synthesis gas can be produced by steam / methane reforming. This unit operation will replace the electrolytic hydrogen facility now used, releasing about 1.34 x $109 \mathrm{kwh} / \mathrm{yr}$ of electric power for other uses. The steam / methane reforming process proposed for the Aswan complex uses modern technology and produce sufficient gas to manufacture 1,200 mt/d of ammonia. Ammonia is the main element in the fertilizers industry (KIMA Board Reports, (2011/2012 - 2014/2015)).

The main characteristics of the new intended plant (the intended ammonia / urea plant) are as follows: Natural gas feed is 1.2 MMSCMD.Ammonia production is 1200 MTPD. 300 MTPD will be directed 
to the existing complex. The balance will be utilized in the urea production (1600 MTPD). Depend on the duration of production 330 day / year. The total financing required for the project is estimated at US\$ $\vee \wedge \vee$ million.The Project execution time is 33 months.Payback Period is about 9 years.The project would be financed on approximately US\$ 363.8 million equity basis, and US\$ 213 million Plus E.P 210 million loan basis.The economic rate of return is $17 \%$

The New intended project (Ammonia/Urea plant) includes: phasing out the uneconomic units which are based on the highly energy-intensive electrolytic process. Installing modern, economic-size plants including a 1,200 tpdammonia plant (based on domestic fuel oil as feedstock), a 1.840 tpd Nitric Acid plant, 1600 tpd Urea, and a 2,400 tpdammonium nitrate. Modernizing the product bagging and loading systems. Providing required technical assistance and training to "KIMA" to improve its production, and maintenance, Thus the holding company for chemical industries will improve its performance evaluation and monitoring functions with respect to the public sector chemical enterprises under its jurisdiction.

The main objectives of the proposed project are to: Finance priority investment in the fertilizer industry,conserve energy and eliminate pollution at "KIMA". Expand fertilizer production at "KIMA" using local resources to reduce dependence on imports. Increase private participation in "KIMA", the project sponsor. Introduce public enterprise reforms on a pilot basis in "KIMA" and in the holding company for chemical enterprises. 
The main benefits from the proposed project would arise from: phasing out the uneconomic units at "KIMA", thus saving about $212 \mathrm{MW}$ of power to the national grid for use elsewhere in the country. Installation of a new fertilizer complex to augment fertilizer supply to facilitate agricultural growth. Decreasing dependence on imported fertilizer and the additional fertilizer production quantityis about 1.4 billion tonsplus $25 \%$ as exports. Improvement in the efficiency of bagging and loading, thus reducing losses;

Elimination of the serious pollution problem at "KIMA" mainly from the existing nitric acid and ferrosilicon units. Improvements in the operating efficiency of "KIMA" and holding company. The production quantity of nutrient fertilizer will increase from 100.000 tons/yr. (before the project) to 220,000 tons/yr. plus 530,000 tons/yr. urea $46.5 \%$ (after the project), and consequently; the annual production value will increase from E.P 222.7 million (before the project) to at least E.P 1.5 Billion (after the project).

Regarding topreviously mentioned research hypothesis; in "KIMA" firm case; the harmful environmental effects are clearly shown in wasting large quantity of resources, environmental damages, harmful emissions and extra harmful leaking of chemical substances during every and repeated times of manufactures stoppings (plant stops). Also; wasting large quantity of energy (electricity and heat) due to the non-presence of a cogeneration unit. All these aspects can be changed to positive direction through investments in the natural gas-based "KIMA" new project.The more efficient investments in chemical industries the les the harmful environmental effects of chemical industries. 
Keeping on raw materials, energy savings and leaking prevention lead to reducing costs, increasing production and increasing benefits (revenue). The revenues will be reflected positively on the financial position of the "KIMA" company and it moves to the high rank of competition with the other of the fertilization producers. It means that the less the harmful environmental effects of chemical industries the more investments economic benefits in chemical industries.Investments in the natural gas-based "KIMA" new project includes the costs of many items that prevent or minimize pollution such as costs of corrosion repairing, costs of filters, and costs of replacing damaged parts.It means thatthe more the costs of pollution prevention the less the harmful environmental effects of the chemical industries.

\section{RECOMMENDATIONS}

1. It is recommended that the firm's management taking the proposed model for the accounting disclosure of environmental information. As that disclosure has great importance in the field of planning and controlling to protect the environment from pollution risks caused by the chemical firms.

2. Developing the standardized (unified) accounting system to suit the modern developments such as environmental accounting requirements and so by reviewing the accountingmanual, final accounts, and financial statements to include the appropriate accounts, such as environmental cost,Environmental commitments and all environmental assets.

3. It is recommended that the firm's management give more attention for the efficient investments with great feasibility studies. Such investment has 
economic; "more financial benefits" and environmental benefits; "less harmful environmental effects".

4. Development of legislation and laws that require firms to take all necessary measures to curb the phenomenon of pollution resulting from the exercise of their production activities, as well as the issuance of an environmental accounting standard.

\section{REFERNCES}

Abdul Hadi Al-Rifai, Baseel Asaad and Elham Battikh, (2008):.The Environmental Pollution due to Heavy Industry and Trying to measure it within accounting frame, Applied study on Banias Refinery Company,Tishreen University Journal for Research and Scientific Studies - Economic and Legal Sciences Series Vol. (30), No. (3), 2008, PP. 217-235.

AhssanZeab Abd, (2008): TahlilAltakalifAlbeiea $\quad$ Fi AlsharhaAlamaLelasmantAlshamalia, Analysis of Enviromnmental Costs in The Northen Public Cement Company, Administartive\& Economics Journal Iraq Academic Scientific Journals (IASJ), 2008, No. 71, PP. 26-50.

CIHC Board Reports (Chemical Industries holding company) General Assembly,(2011/2012 - 2014/2015).

EPA E., (1997): Environmental Disclosure, Accounting Journal, Vol.50, No.13, PP.85-86, 1997.

EPA E., (1999): Environmental Liabilities, Accounting Journal, Vol.70, No 36, PP100-101, 1999.

JūrateJaraitė, Andrius Kažukauskas, and Tommy Lundgren, (2012): Determinants of environmental expenditure and investment: evidence from Sweden, CERE Working Paper No 2012:7, 17 pages,Available at http://ssrn.com/abstract=2006990.

KIMA Board Reports of General Assembly, (2011/2012 - 2014/2015). 
SEMADCO Board Reports of General Assembly, (2011/2012 - 2014/2015).

S\&WMCI STONE \& WEBSTER Management Consultant, Inc., (1998): EPYPT: Pre-investment analysis of alternatives for increasing nitrogen fertilizer production in upper Egypt, United states, Agency for International Development, Pages. 1-5.

UNCTAD Secretariat,(1998): Environmental Financial Accounting And Reporting At The Corporate Level, Geneva, 11-13 February 1998.

UNDSD United Nations Division for Sustainable Development, (2001), Environmental Management Accounting Procedures and Principles, United Nations, New York, 2001.

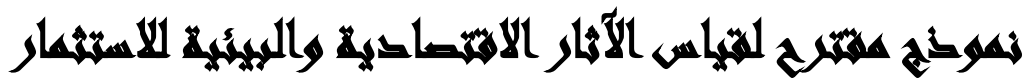

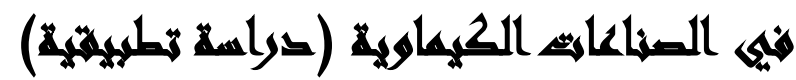

[ᄉ]

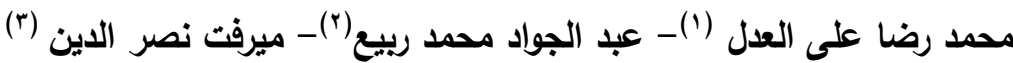

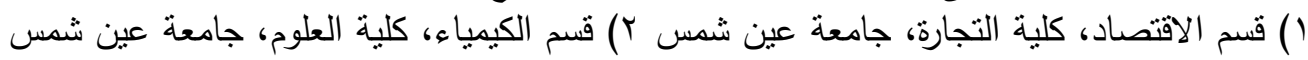

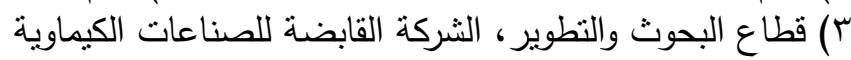

\section{المستطلم}

طبقا لمفهوم التتمية المستدامة فإنه توجد علاقة هامة بين التتمية الاقتصادية وحماية البيئة من

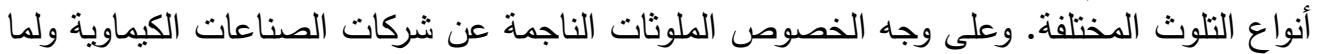

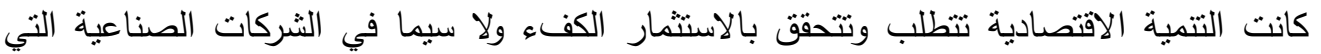

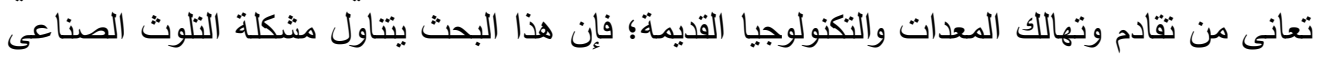

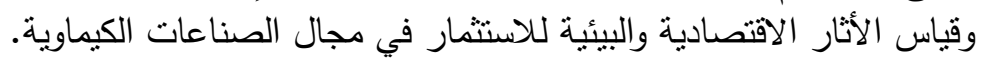

